ENTREPRENEURSHIP AND SUSTAINABILITY ISSUES

ISSN 2345-0282 (online) http://jssidoi.org/jesi/ 2020 Volume 8 Number 1 (September)

http://doi.org/10.9770/jesi.2020.8.1(3)

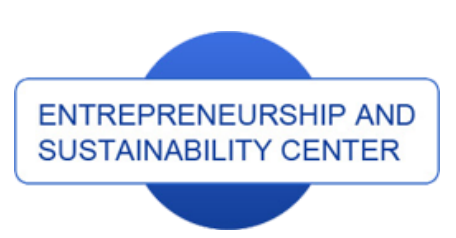

Publisher

http://jssidoi.org/esc/home

\section{enterprise europe network}

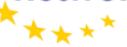

Business Support on Your Doorstep

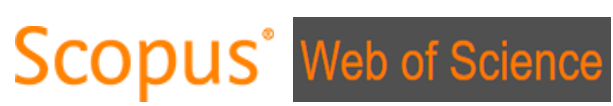

1) Clarivate

Analytics

\title{
INDIVIDUAL AND ORGANIZATIONAL FACTORS' EFFECT ON KNOWLEDGE SHARING BEHAVIOR
}

\author{
Abdul Rohman ${ }^{1}$, Anis Eliyana ${ }^{2}$, Dedi Purwana ${ }^{3}$, Hamidah 4 \\ ${ }^{1}$ Universitas Negeri Jakarta, Rawamangun Muka Jakarta, Indonesia \\ ${ }^{2}$ Universitas Airlangga, Airlangga 4-6 Surabaya, Indonesia \\ ${ }^{3,4}$ Universitas Negeri Jakarta, Rawamangun Muka Jakarta, Indonesia \\ E-mails: ${ }^{1}$ abdulrohman_9917917016@mhs.unj.ac.id ; ${ }^{2}$ anis.eliyana@feb.unair.ac.id; \\ 3dpurwana@unj.ac.id; ${ }^{4}$ hamidah@unj.ac.id
}

Received 20 March 2020; accepted 20 June 2020; published 30 September 2020

\begin{abstract}
This paper aims to assess the impact of individual factors (interpersonal trust, individual attitude, perceived benefit/costs, and individual self efficacy) and organizational factors (management support, incentives/reward, leadership, and organizational culture) on knowledge sharing intention and their impact to knowledge sharing behavior. The data were obtained by using questionnaires distributed to all researchers and staffs at Cancer Research Center C-Tech Labs Edwar Technology with 100 samples taken. This research center is the only Lab Cancer in Indonesia. Structural Equation Modeling (SEM) analysis was used to ascertain the proposed relationship. The present study found that four dimensions of individual factors (interpersonal trust, individual attitude, perceived benefit/costs, and self-efficacy) and four dimensions of organizational factors (management support, incentives/reward, leadership, and organizational culture) were significantly related to knowledge sharing intention and they mediate to knowledge sharing behavior.
\end{abstract}

Keywords: individual factors; organizational factors; knowledge sharing intention; knowledge sharing behavior

Reference to this paper should be made as follows: Rohman, A., Anis Eliyana, A., Purwana, D., Hamidah. (2020). Individual and organizational factors' effect on knowledge sharing behavior. Entrepreneurship and Sustainability Issues, 8(1), 38-48. http://doi.org/10.9770/jesi.2020.8.1(3)

JEL Classification: 015

\section{Introduction}

Research Center is a specific entity with different characteristics in handling human resources, as the characteristics of human resources in research institutions vary significantly from non-research human resources. In addition, the research center also has important things in their management, namely knowledge management as a place to manage both existing and future knowledge. A research center is an institution of research and development (R\&D) that has management, vision and mission in a systemic way. The primary function of R\&D organizations is to ensure the collection and exchange of information for an ongoing process of knowledge creation (Berends et al., 2006). 


\section{ENTREPRENEURSHIP AND SUSTAINABILITY ISSUES}

ISSN 2345-0282 (online) http://jssidoi.org/jesi/ 2020 Volume 8 Number 1 (September)

http://doi.org/10.9770/jesi.2020.8.1(3)

At the research center, knowledge management is based fundamentally on the principle of knowledge formation founded by Nonaka (1994) and Takeuchi \& Umemoto (1996) in A Dynamic Theory of Organizational Knowledge Creation. This definition was commonly formulated not exclusively for one or two types of organizations, but for the form of organization as a whole, including the organization of the research center. That is, every organization has the opportunity to enhance knowledge within their organization.

Bock, et al., (2016) revealed that innovation capacity for a company can be enhanced by knowledge sharing. In organizations such as research centers, this improvement in innovation has become very significant as this institution generates a lot of innovations and developments. Research developments are generated daily through a set of validated methods and procedures.

Practitioners have several concerns about whether and how to enforce knowledge sharing in organisations, and what factors can promote and impede implementation. Many studies have found models and ways to answer this issue, both quantitatively and qualitatively. One of the findings of the researchers' discussion is the findings of Pedersen's (2017) study, which notes that human factors, organizational factors and technical factors affect the sharing of knowledge among individuals. While Akhavan et al. (2013) argue that intrinsic motivational factors, extrinsic motivational factors and expectations or preferences for the process of information sharing gave rise to the interest of employees in sharing knowledge with others. A separate stream of papers is devoted to clusters, which are considered knowledge sharing and technology transfer vehicles (e.g. Androniceanu, Tvaronavičiené, (2019); Bublienė et al. (2019); El Idrissi et al. (2020); Laužikas, Miliūtè, (2020)).

\section{Literature Review}

\section{Individual Factors}

\section{a. Interpersonal Trust}

Trust is a multifaceted concept which conveys beliefs or expectations about other parties resulting from the party's facts, purpose, honesty, kindness or reliability (Cheng et al., 2008). Employees tend to share knowledge among themselves within trusted organisations (Abrams et al., 2003). Earlier studies found out that trust among coworkers is an essential element that was considered to have a significant impact on the sharing of knowledge (Al-Alawi et al., 2007a; Wang \& Noe, 2010). Bakker, et al. (2006) also argue that in order to share knowledge effectively, trust among individuals is needed. In addition, a study carried out by Issa \& Haddad (2008) shows that sharing knowledge that exists inside and throughout the organization requires mutual trust among employees. These studies suggest that mutual trust tends to affect knowledge sharing.

\section{b. Individual Attitude}

Values and attitudes affect human behaviour, in general. Several studies even suggest that attitudes of each individual may influence the process of knowledge sharing. For example Bock \& Kim (2001) demonstrated that individuals preferences regarding their knowledge value or when shared with others will strengthen their relationships and are associated with positive attitudes to knowledge sharing. They also emphasized that this was linked to intention and behavior of knowledge sharing. Likewise, knowledge sharing behaviors had an effect on knowledge sharing either direct and indirect (Bock et al., 2005; Lin, 2008). Additionally, indirect effects are found linked to self-reported sharing behaviors through the positive influence of the willingness to share. Overall , these researches show that individual attitude is an essential factor which influences the desire to share knowledge.

\section{c. Perceived benefits/costs}

Most studies have put their concern on the perceived benefits / costs as one of the antecedent variables of knowledge sharing (Wang \& Noe, 2010). However, theory of social exchange supports the idea that each individuals consider perceived cost-benefit ratios and make decisions based on assumptions that will result in benefits such as acknowledgement, appreciation and extrinsic incentives. According to this theory, research 


\section{ENTREPRENEURSHIP AND SUSTAINABILITY ISSUES}

ISSN 2345-0282 (online) http://jssidoi.org/jesi/

2020 Volume 8 Number 1 (September)

http://doi.org/10.9770/jesi.2020.8.1(3)

shows that the benefits felt contribute positively to the exchange of information (Wang \& Noe, 2010). Furthermore, most benefits / cost are perceived within the professional community. Previous studies have shown that the sharing of knowledge is strongly connected to individual beliefs that their shared information benefits others, particularly in professional networks (Chiu et al., 2006; Siemsen et al., 2007).

\section{d. Individual self-efficacy}

Self-efficacy in relation to individual expectations regarding their ability to perform tasks is the key motivational cognitive mediator (Bandura, 2000) and is the indicator of knowledge sharing (Lee \& Ahn, 2007). Consequently, the self-efficacy mechanism is thought to provide crucial facts on how each persons wish to convey specific knowledge. For example, as individuals establish expectations of self-efficacy about their success in a particular area this perception is mirrored in their trust systems (Lee \& Ahn, 2007). So self-efficacy in the ability to share information can have an impact on the sharing of knowledge. Higher self-efficacy in the willingness of individuals to share information may lead to personal challenges, greater engagement and perseverance and greater happiness and achievement (Bandura, 2000). The self-efficacy principle believes that stronger selfefficacy fosters individuals to be more secured in their performance.

\section{Organizational Factors}

\section{a. Management Support}

Management has a crucial role in the development of efficient knowledge sharing. Active participation and management engagement builds knowledge sharing routine and is crucial to evaluate the effectiveness of knowledge sharing process. Support from top management improves the staffs' willingness to communicate and gain knowledge within the organisation (Wee, 2012). Management support is identified as one of the main factors affecting employees' perceptions about knowledge sharing behaviour and knowledge sharing ability (S. Wang \& Noe, 2010). Lee, (2006) found that support from top management affected productivity and knowledge sharing level by influencing employee commitment to KM. Wang dan Noe (2010) also indicated that the strong indicator of employee knowledge sharing behaviour is the management support to knowledge sharing. These studies show that top management support may influence knowledge sharing.

b. Incentives/Rewards

Through cultures, incentives were regarded as the main driving force for knowledge-sharing (Yao et al., 2007). A research by Kim \& Lee (2006) found that companies that prioritize performance-based programs contribute to knowledge sharing. Both theories of social exchange and social capital support the claim that organizational incentives, such as pay rises, bonuses and promotions, are related to knowledge sharing among employees. According to Nelson dan Sabatier (2006), recognition and rewards play an important role in the promotion of knowledge sharing and in the creation of a support network. To summarize, these studies suggest that incentives / rewards can affect the knowledge sharing.

c. Leadership

A leader is a determinant of the organization's course and goals, and must be ready to respond to growth (Eliyana 2010). Leadership is very central to the discussion about information systems and management in academic literature. Leadership style is associated with the acts of a leader when leading his followers or providing guidance. Leadership styles include authoritarian, egalitarian, transactional, and transformational. A good leader serves as a role model and in a way that encourages knowledge sharing and provides incentives to do so (Søndergaard et al., 2007). Chen et al (2004) found transformational leadership behavior to be an essential predictor of knowledge sharing.

\section{d. Organizational Culture}

Organizational culture refers to common values, beliefs and standards that are accepted by the members of the organization. Organizational culture is an important element in the sharing of information inside and outside the organization (Lee \& Ahn, 2007). Therefore, culture that promotes knowledge sharing can contribute to an 
efficient KM network. Al-Alawi et al. (2007) found that sharing knowledge is a constructive part of organisation's culture. Whereas Connelly dan Kelloway (2003) state that workers will be able to exchange knowledge in a stimulating environment. For the exchange of useful knowledge in the organizational, cultural elements are very important (Søndergaard et al., 2007). From this analysis it is evident that knowledge sharing increases with the organizational culture.

\section{Knowledge Sharing}

Knowledge sharing is considered to be the inseparable part of knowledge management. It is consistent with the view that knowledge-management systems depend on success on knowledge sharing (Wang \& Noe, 2010). The sharing of knowledge is defined as group activities which promote learning and enhance the group's ability to achieve objectives (Rosendaal \& Bijlsma-Frankema, 2015). Rutten et al. (2016) notes that employee trust affects company performance while high trust value will also influence the value of information sharing. knowledge sharing is a method of social interaction involving the exchange of knowledge, expertise and skills among employees across departments or organisations. This opinion directs that the sharing of information is in fact an operation of social interaction between human subjects to share knowledge, experience and skills that someone possesses so that knowledge can be spread and used to gain potential improvements. Several other definitions of knowledge sharing which were also presented in the study by Farooq (2018) can be read in the following table 1:

Table 1. Conceptual Model of Knowledge Sharing

\begin{tabular}{|c|c|c|c|}
\hline No & Construct & Definition & Source \\
\hline 1 & $\begin{array}{l}\text { Knowledge } \\
\text { sharing }\end{array}$ & $\begin{array}{l}\text { Sharing of knowledge is a mechanism by which individuals } \\
\text { and groups unintentionally or intentionally transfer their } \\
\text { knowledge for their mutual benefit }\end{array}$ & $\begin{array}{l}\text { Nooshinfard } \\
\text { Nemati-Anaraki, } \\
(2014)\end{array}$ \\
\hline 2 & $\begin{array}{l}\text { Knowledge } \\
\text { sharing }\end{array}$ & $\begin{array}{l}\text { Sharing of knowledge is described as one's expectations of } \\
\text { knowledge and information exchange in order to support } \\
\text { the organization of sharers }\end{array}$ & $\begin{array}{l}\text { Witherspoon et al., } \\
\text { (2013) }\end{array}$ \\
\hline 3 & $\begin{array}{l}\text { Knowledge } \\
\text { Sharing }\end{array}$ & $\begin{array}{l}\text { Sharing of knowledge is the practice by which knowledge } \\
\text { providers within the company make information accessible } \\
\text { to others }\end{array}$ & $\begin{array}{l}\text { Wickramasinghe } \quad \& \\
\text { Widyaratne, }(2012)\end{array}$ \\
\hline 4 & $\begin{array}{l}\text { Knowledge } \\
\text { Sharing }\end{array}$ & $\begin{array}{l}\text { Sharing of knowledge is described as a group activity } \\
\text { which encourages learning and improves the ability of the } \\
\text { group to achieve its objectives }\end{array}$ & $\begin{array}{l}\text { Rosendaal \& Bijlsma- } \\
\text { Frankema, (2015) }\end{array}$ \\
\hline 5 & $\begin{array}{l}\text { Knowledge } \\
\text { Sharing }\end{array}$ & $\begin{array}{l}\text { Sharing of knowledge is a complex learning mechanism in } \\
\text { which both implicit and explicit information is used to } \\
\text { create awareness in organizations }\end{array}$ & Swift \& Hwang (2013) \\
\hline 6 & $\begin{array}{l}\text { Knowledge } \\
\text { Sharing }\end{array}$ & $\begin{array}{l}\text { Sharing of knowledge refers to the mechanism by which } \\
\text { team members exchange task-related ideas, information, } \\
\text { improvements and suggestions among themselves }\end{array}$ & $\begin{array}{l}\text { Eze, Goh, Goh, \& Tan } \\
\text { (2013) }\end{array}$ \\
\hline 7 & $\begin{array}{l}\text { Knowledge } \\
\text { Sharing }\end{array}$ & $\begin{array}{l}\text { Sharing of knowledge is described as the actions by which } \\
\text { a person gives others some form of access to his or her } \\
\text { knowledge and experience within the organization }\end{array}$ & $\begin{array}{l}\text { Peyman Akhavan et } \\
\text { al., (2013) }\end{array}$ \\
\hline 8 & $\begin{array}{l}\text { Knowledge } \\
\text { Sharing }\end{array}$ & $\begin{array}{l}\text { Sharing of knowledge is the process by which members of } \\
\text { the company share their knowledge and experiences to } \\
\text { increase learning capacity and develop new knowledge }\end{array}$ & $\begin{array}{l}\text { Islam, Jasimuddin, \& } \\
\text { Hasan (2015) }\end{array}$ \\
\hline 9 & $\begin{array}{l}\text { Knowledge } \\
\text { Sharing }\end{array}$ & $\begin{array}{l}\text { Sharing of knowledge is an important strategic tool in } \\
\text { organizations, and an essential resource for achieving } \\
\text { competitive advantage }\end{array}$ & $\begin{array}{l}\text { Siakas, Georgiadou, \& } \\
\text { Balstrup (2010) }\end{array}$ \\
\hline 10 & $\begin{array}{l}\text { Knowledge } \\
\text { Sharing }\end{array}$ & $\begin{array}{l}\text { Sharing of knowledge is described as individuals' } \\
\text { willingness to share their knowledge with others within the } \\
\text { organization }\end{array}$ & Rutten et al., (2016) \\
\hline 11 & $\begin{array}{l}\text { Knowledge } \\
\text { Sharing }\end{array}$ & $\begin{array}{l}\text { Sharing of knowledge is a process of exchanging both } \\
\text { implicit and explicit information to produce new } \\
\text { knowledge }\end{array}$ & $\begin{array}{l}\text { Razmerita, Kirchner, } \\
\text { \& Nielsen (2016) }\end{array}$ \\
\hline
\end{tabular}




\begin{tabular}{lll}
\hline 12 & $\begin{array}{l}\text { Knowledge } \\
\text { Sharing }\end{array}$ & $\begin{array}{l}\text { Sharing of knowledge is a two-pronged mechanism by } \\
\text { which one possesses the knowledge and another acquires } \\
\text { the knowledge and thus effective communication becomes } \\
\text { essential in the knowledge sharing mechanism }\end{array}$ \\
\hline 13 & $\begin{array}{l}\text { Knowledge } \\
\text { Sharing }\end{array}$ & $\begin{array}{l}\text { Sharing of knowledge orientation stands for the } \\
\text { organization's propensity to promote, enable and reward the } \\
\text { exchange of knowledge with a motivation to obtain tacit } \\
\text { and explicit learning from employees }\end{array}$ \\
\hline & $\begin{array}{l}\text { Knowledge } \\
\text { Sharing }\end{array}$ & $\begin{array}{l}\text { Shang of knowledge is the basic means by which workers } \\
\text { and ultimately the competitive advantage }\end{array}$ \\
\hline
\end{tabular}

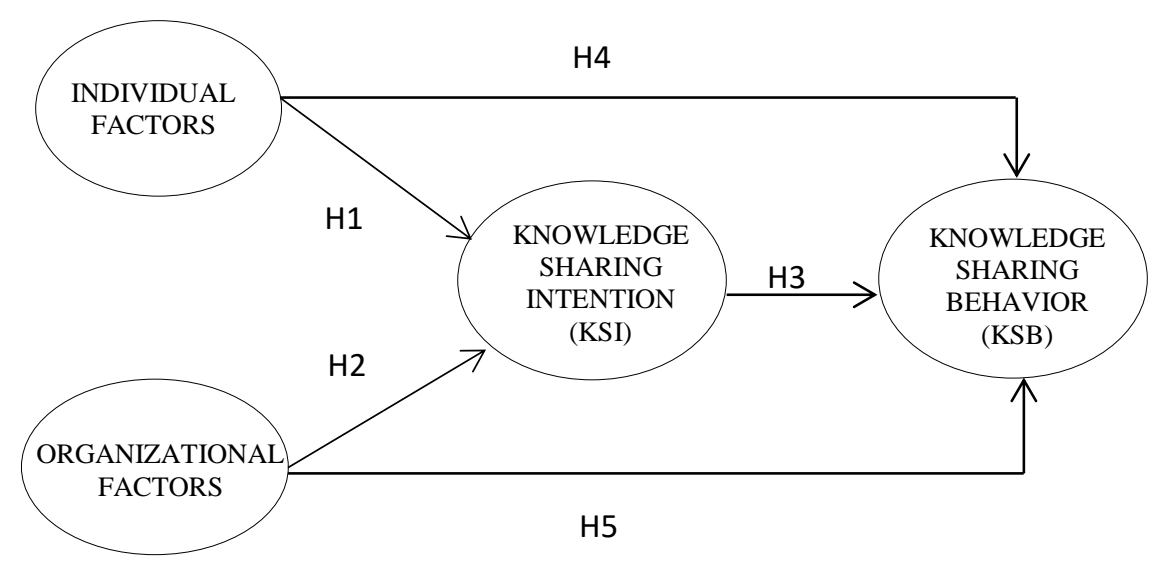

Figure 1. Research Model

\section{Hypotheses}

H1. Individual factors are positively related to knowledge sharing intention.

$\mathrm{H} 2$. Organizational factors are positively related to knowledge sharing intention.

$\mathrm{H} 3$. Knowledge sharing intention is positively related to knowledge sharing behavior.

$\mathrm{H} 4$. Individual factors are positively related to knowledge sharing behavior.

H5. Organizational factors are positively related to knowledge sharing behavior.

\section{Method}

\section{Sample and data collection procedure}

We conducted a survey among researchers and staff at the C-Tech Labs Edwar Technology cancer research center located in the Province of Banten, Indonesia, to gather data. At this institution the study population was a total of 150 researchers and staff, 100 of whom were taken as the sample. Several visits were made to get relevant data. At the beginning of the study the researchers and staff were interviewed to get a first-hand overview of the science field. Research Model is presented in figure 1 above.

\section{Measures}

Measurement of individual factors, organizational factors, purpose to share knowledge, and actions to share knowledge was taken from Pedersen (2017) and Akhavan et al. (2013), who built the instruments from previous works. Following their instrument, we used sixteen items to calculate individual factors, sixteen items for 
ENTREPRENEURSHIP AND SUSTAINABILITY ISSUES

ISSN 2345-0282 (online) http://jssidoi.org/jesi/ 2020 Volume 8 Number 1 (September) http://doi.org/10.9770/jesi.2020.8.1(3) organizational factors, five items for knowledge sharing intention and six items for knowledge sharing behavior. All items were measured on a five-point Likert-type, ranging from strongly disagree (1) to strongly agree (5).

For more details, sixteen items of the individual factors included items of interpersonal trust, individual attitude, perceived benefits/cost, and self efficacy. Additionally, management support, incentives / rewards, leadership, and corporate culture are all part of the knowledge sharing corporate factors. In addition, knowledge-sharing goals and knowledge-sharing behavior are directly related to the questions.

\section{Data Analysis}

The Structural Equation Model (SEM) is the data analytics techniques used to address the issue in this study. There may also be a variable which plays a multiple role as independent variables in a relationship, but becomes dependent on another relationship in effect of tiered causality relationship. That dependent and independent variables may appear as factors constructed from multiple indicator variables. Similarly, in a research phase the variables can appear in the form of a single variable directly observed or calculated.

SEM modeling tested hypotheses that must be fulfilled with the following parameters in data collection and processing procedures: (1) sample size, (2) normality and linearity, (3) outliers, (4) multicollinearity, and (5) singularity. After testing SEM hypotheses, the next issue is to determine which parameters should be used to measure the experiment and the results found in the experiment. In general, the various fit index types are used to measure the degree of correlation between the model expected by the presented data. Researchers are required to use few fit indexes to test the proposed model to measure the "truth."

Some suitability index and the cut-off value is used in examining whether a model can be accepted or rejected are as described below: (1) Chi-Square Statistic, (2) RMSEA (Root Mean Square Error of Approximation), (3) GFI (Goodness of Fit Index), (4) AGFI (Adjusted Goodness of Fit Index), (5) CMIN / DF, (6) TLI (Tucker Lewis Index), and (7) CFI (Comparative Fit Index).

\section{Results}

The result of data analysis were processed using AMOS program version 2.1. By using Structural Equation Modelling (SEM) analysis, the estimation is conducted in several stages. First, it is conducted by performing Confirmatory Factor Analysis technique and second, it continues to the Full Structural Equation Model.

\section{Confirmatory Factor Analysis}

There are two measurenment tests on confirmatory factor analysis, namely Goodness of Fit Test and Weight Factor Significance Test. This research will show the result of Goodness of Fit index Test which has standard of cut off value result (see table 2).

Table 2. Goodness of Fit Index Test Result

\begin{tabular}{lcccccc}
\hline \multicolumn{1}{c}{$\begin{array}{c}\text { Goodness of Fit } \\
\text { Index }\end{array}$} & Cut off Value & \multicolumn{4}{c}{ Result } & $\begin{array}{c}\text { Model } \\
\text { Evaluation }\end{array}$ \\
\cline { 3 - 6 } Chi-Square (df=98) & Small $(<122,108)$ & 1,904 & 1,393 & 0,528 & 0,668 & Good \\
Probability & $>0,05$ & 0,386 & 0,498 & 0,768 & 0,716 & Good \\
RMSEA & $<0,08$ & 0,000 & 0,000 & 0,000 & 0,000 & Good \\
GFI & $>0,90$ & 0,991 & 0,993 & 0,997 & 0,997 & Good \\
AGFI & $>0,90$ & 0,955 & 0,965 & 0,987 & 0,983 & Good \\
CMIN/DF & $<2,00$ & 0,952 & 0,695 & 0,264 & 0,334 & Good \\
CFI & $>0,95$ & 1,000 & 1,000 & 1,000 & 1,000 & Good \\
\hline
\end{tabular}




\section{ENTREPRENEURSHIP AND SUSTAINABILITY ISSUES}

ISSN 2345-0282 (online) http://jssidoi.org/jesi/ 2020 Volume 8 Number 1 (September) http://doi.org/10.9770/jesi.2020.8.1(3)

This table shows that the value of Chi-Square individual factors $(1,904)$, organizational factors $(1,393)$, knowledge sharing intention $(0,528)$, and knowledge sharing behavior $(0,668)$ with a significance level of Chi-Square individual factors $(0,386)$, organizational factors $(0,498)$, knowledge sharing intention $(0,768)$, and knowledge sharing behavior $(0,716)$. It indicates that the null hyphotesis stated that there is no difference between sample covariance matrix and estimated population covariance matrix received. Therefore, it means the model fits. Likewise, the measures of the other eligibility resulted in good criteria.

\section{Full Model of SEM Analysis}

After measuring the models analyzed by confirmatory factor analysis and observing that each indicator could be used to define latent constructs, a full model of SEM could be analyzed (figure 2).

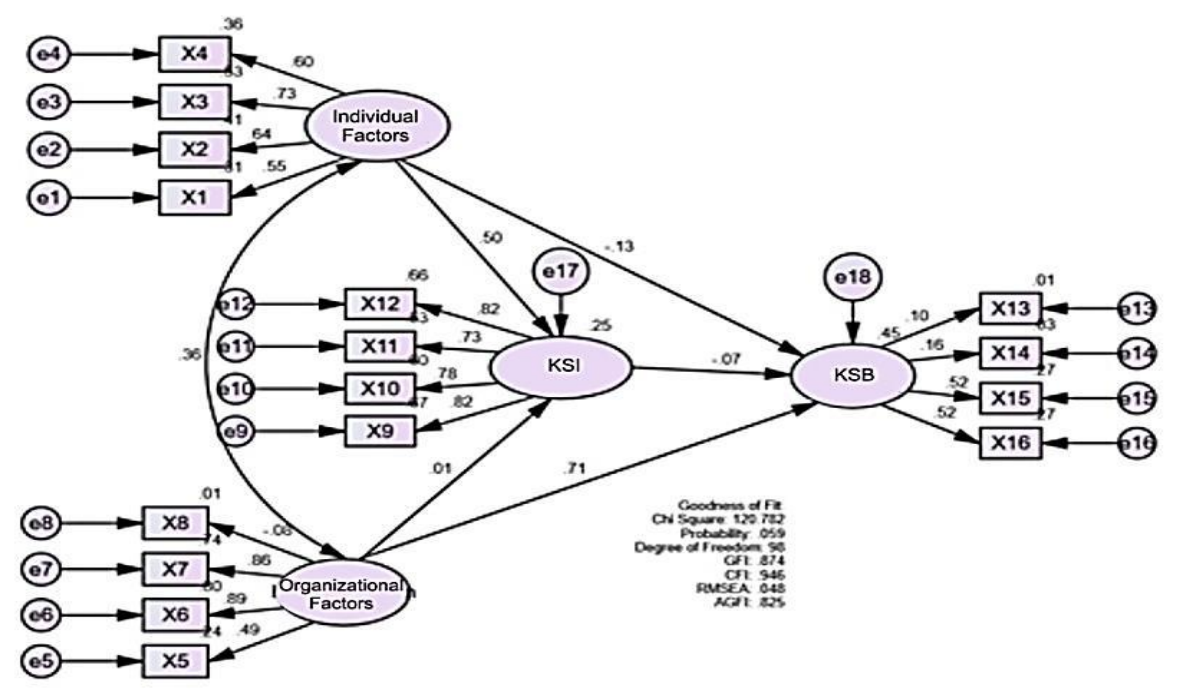

Figure 2. Structural Equation Model (SEM) Analysis Result

Table 3. Full Model SEM Feasibility Testing Result

\begin{tabular}{lccc}
\hline \multicolumn{1}{c}{ Goodness of Fit Index } & Cut off Value & Result & Model Evaluation \\
\hline Chi-Square $(\mathbf{d f}=98)$ & Small $(<122,108)$ & 120,782 & Good \\
Probability & $>0,05$ & 0,059 & Good \\
RMSEA & $<0,08$ & 0,048 & Good \\
GFI & $>0,90$ & 0,874 & Marginal \\
AGFI & $>0,90$ & 0,825 & Marginal \\
CMIN/DF & $<2,00$ & 1,232 & Good \\
CFI & $>0,95$ & 0,946 & Good \\
\hline
\end{tabular}

Based on the results presented in Table. 3, the value of Chi Square is 120,782 with probability $=0,059$. This indicates that the null hyphotesis which states that there is no difference between the sample covariance matrix and estimated population covariance matrix is acceptable. Other indexes are also within the range of expected values, therefore the result of this model is acceptable (table 4). 
ENTREPRENEURSHIP AND SUSTAINABILITY ISSUES

ISSN 2345-0282 (online) http://jssidoi.org/jesi/ 2020 Volume 8 Number 1 (September) http://doi.org/10.9770/jesi.2020.8.1(3)

Table 4. Hypothesis Test Result

\begin{tabular}{|c|c|c|c|c|c|c|}
\hline & & Std.Est & Estimate & $\mathbf{S E}$ & $\mathbf{C R}$ & $\mathbf{P}$ \\
\hline KS Intention & $\longleftarrow$ Individual F. & 0.497 & 0.737 & 0.236 & 3.119 & 0.002 \\
\hline KS Intention & $\longleftarrow$ Organizational F. & 0.010 & 0.021 & 0.259 & 3.080 & 0.001 \\
\hline KS Behavior & $4 \quad$ Individual $\mathrm{F}$. & 0.133 & 0.025 & 0.052 & 3.477 & 0.003 \\
\hline KS Behavior & Organizational F. & 0.708 & 0.193 & 0.294 & 3.656 & 0.004 \\
\hline KS Behavior & $\longleftarrow$ KS Intention & 0.071 & 0.009 & 0.028 & 3.319 & 0.003 \\
\hline
\end{tabular}

First, parameter estimation on the effect of individual factor on knowledge sharing intention showed CR value of 3.119 with a probability of 0.002 or it is $<0.05$. It could be concluded that the individual factors variables affect the knowledge sharing intention. Second, Parameter estimation on the effect of organizational factor on knowledge sharing intention showed CR value of 3.080 with a probability of 0.001 or it is $<0.05$. It could be concluded that the organizational factors variable affects the knowledge sharing intention. Third, parameter estimation on the effect of individual factor on knowledge sharing behavior showed CR value of 3.477 with a probability of 0.003 or it is $<0.05$. It could be concluded that the individual factors variables affect to the knowledge sharing behavior. Fourth, parameter estimation on the effect of organizational factor on knowledge sharing behavior showed CR value of 3.656 with a probability of 0.004 or it is $<0.05$. It could be concluded that the organizational factors variables affect the knowledge sharing behavior. And the last, parameter estimation on testing the effect ofknowledge sharing intention on knowledge sharing behavior showed CR value of 3.319 with a probability of 0.003 or it is $<0.05$. It could be concluded that the knowledge sharing intention variables affect the knowledge sharing behavior.

\section{Discussion}

In the present study, the indirect effect of two knowledge sharing factors (individual and organizational factors) on knowledge sharing activity was explored through the mediation of knowledge sharing intention. We found these two variables to be directly influenced by the behavior of knowledge sharing through the intent of knowledge sharing. The impact of individual facts and organizational variables shown in this research is consistent with past work (e.g., Pedersen, 2017; Akhavan et al., 2013; Tan et al., 2013; Shin-Yuan et al., 2011). Detailed discussion should be examined as a recommendation of this study on the dimensions of each variables.

Furthermore, the study results show that all dimensions of individual factors (interpersonal trust, individual attitude, perceived benefit / cost, and self-efficacy) influence the conduct of knowledge sharing through the intention to share information. The interpersonal trust is one of the strongest dimensions of individual factors. Such findings indicate the role of the interpersonal trust element in the sharing of information (e.g., Niedergassel et al., 2011; Tan et al., 2013). Interpersonal trust becomes very important in research institutions because it deals with copyright, patents and matters relating to Intellectual Property Rights (IPR). In addition, the results of the research on the dimensions of organizational factors (management support, incentives/reward, leadership, and organizational culture) also show results that influence the knowledge sharing behavior. One dimension that is very influential is organizational culture. This reinforces the opinion of previous research by Tan et al., (2013) and Rego et al., (2009). In addition to being an enabler for knowledge sharing, organizational culture can also be a barrier. As research conducted by Kosonen and Kianto (2007).

The most important thing is that the results of this study strengthen the results of previous studies, however, researchers also found other factors besides individual factors and organizational factors, namely technological factors. This technological factor has also been studied by Kosonen and Kianto (2007). However, there is not too much literature discussing technological factors. Even though this technology factor is quite important in promoting and implementing knowledge sharing in research organization. 


\section{ENTREPRENEURSHIP AND SUSTAINABILITY ISSUES}

ISSN 2345-0282 (online) http://jssidoi.org/jesi/ 2020 Volume 8 Number 1 (September) http://doi.org/10.9770/jesi.2020.8.1(3)

\section{Implications and Limitations}

The results of this study have beneficial implications for research institutions, especially regarding the framework of knowledge management. The findings remind us of the need for a research center to strengthen its dedication to knowledge management program and its intention to share knowledge as part of the culture of information sharing behaviour. The study highlights the role of individual and organizational factors in fostering the intention to share knowledge and increasing the sharing of knowledge. In addition, the factors that promote the exchange of knowledge do not only come from individuals and organisations, but also come from technological factors. We emphasize that, when considering such limitations, the results of this study should be interpreted carefully. We independently thought the sample size of 100 participants could be insufficient for objective validity to be developed. We suggest that future research be considered in other government-sector R\&D agencies, in particular.

\section{Conclusion}

A knowledge management program will support the role of research institutions to significantly contribute to the country's economic growth and development. This work has specifically aimed to strengthen the relationship between person and organizational factors with the goal of exchanging knowledge which will eventually increase the conduct of knowledge sharing. Individual factors like interpersonal trust, individual attitude, perceived benefit / cost and individual self-efficacy need to be at the top of the agenda. Furthermore, organizational factors such as support for management, incentive / rewards, leadership, and organizational culture are also strong supporters for advancing the organization. However, in terms of management structure, research institutions are somewhat different from other institutions; thus, there are possibilities for various causes that can have different effects in individuals and organisations.

\section{References}

Abrams, L. C., Cross, R., Lesser, E., \& Levin, D. Z. (2003). Nurturing interpersonal trust in knowledge-sharing networks. Academy of Management Executive, 17(4), 64-77. https://doi.org/10.5465/AME.2003.11851845

Akhavan, P., Rahimi, A., \& Mehralian, G. (2013). Developing a model for knowledge sharing in research centers. Vine, 43(3), 357-393. https://doi.org/10.1108/VINE-06-2012-0020

Al-Alawi, A. I., Al-Marzooqi, N. Y., \& Mohammed, Y. F. (2007). Organizational culture and knowledge sharing: Critical success factors. Journal of Knowledge Management, 11(2), 22-42. https://doi.org/10.1108/13673270710738898

Androniceanu, A., Tvaronavičienè, M (2019). Developing a holistic system for social assistance services based on effective and sustainable partnerships. Administratiesi Management Public, (33), 103-118. https://doi.org/10.24818/amp/2019.33-06

Bakker, M., Leenders, R. T. A. J., Gabbay, S. M., Kratzer, J., \& Van Engelen, J. M. L. (2006). Is trust really social capital? Knowledge sharing in product development projects. Learning Organization, 13(6), 594-605. https://doi.org/10.1108/09696470610705479

Bandura, A. (2000). Exercise of human agency through collective efficacy. Current Directions in Psychological Science, 9(3), 75-78. https://doi.org/10.1111/1467-8721.00064

Berends, H., Bij, H. van der, Debackere, K., \& Weggeman, M. (2006). Knowledge Sharing in Industrial Research. R\&D Management, 36(1), 85-95. https://doi.org/10.1111/j.1467-9310.2005.00417.x

Bock, A. G., Zmud, R. W., Kim, Y., Lee, J., \& Lee, J. (2016). Behavioral intention formation in knowledge sharing: Examining the roles of extrinsic motivators, social-psychological forces, and organizational climate. MIS Quarterly: Management Information Systems, 29(1), 87111 


\section{ENTREPRENEURSHIP AND SUSTAINABILITY ISSUES}

ISSN 2345-0282 (online) http://jssidoi.org/jesi/ 2020 Volume 8 Number 1 (September) http://doi.org/10.9770/jesi.2020.8.1(3)

Bublienė, R., Vinogradova, I., Tvaronavičienè, M., Monni, S. (2019). Legal form determination for the development of clusters' Laužikas, M., Miliūté, A. 2020. Liaisons between culture and innovation: comparative analysis of South Korean and Lithuanian IT companies. Insights into Regional Development, 2(2), 523-537. https://doi.org/10.9770/IRD.2020.2.2(2)

Cheng, J., Yeh, C., \& Tu, C. (2008). Trust and knowledge sharing in green supply chains. Supply Chain Management: An International Journal, 13(4), 283-295. https://doi.org/10.1108/13598540810882170

El Idrissi, N. E. A., Ilham Zerrouk, I., Zirari, N., Monni, S. (2020). Comparative study between two innovative clusters in Morocco and Italy. Insights into Regional Development, 2(1), 400-417. http://doi.org/10.9770/IRD.2020.2.1(1)

Eze, U. C., Goh, G. G. G., Goh, C. Y., \& Tan, T. L. (2013). Perspectives of SMEs on knowledge sharing. Vine, 43(2), 210-236. https://doi.org/10.1108/03055721311329963

Farooq, R. (2018). A conceptual model of knowledge sharing. International Journal of Innovation Science, 10(2), 238-260. https://doi.org/10.1108/IJIS-09-2017-0087

Kim, S., \& Lee, H. (2006). Th e Impact of Organizational Context and Information Technology on Employee Knowledge-Sharing Capabilities Soonhee. Public Administration, 370-385.

Kosonen, M., \& Kianto, A. (2007). Applying wikis to managing knowledge - A socio-technical approach. Proceedings of the European Conference on Knowledge Management, ECKM, 19(1), 541-546. https://doi.org/10.1002/kpm

Laužikas, M., Miliūte, A. (2020). Human resource management effects on sustainability of high-tech companies: what Lithuania and South Korea can learn from each other. Insights into Regional Development, 2(2), 562-579. https://doi.org/10.9770/IRD.2020.2.2(5)

Lee, J.-H. (2006). Effects of Managerial Drivers Performance : Information Resources Management, 19(3), 48-60.

Ma, Z., Huang, Y., Wu, J., Dong, W., \& Qi, L. (2014). What matters for knowledge sharing in collectivistic cultures? empirical evidence. Journal of Knowledge Management, 18(5), 1004-1019. https://doi.org/10.1108/JKM-06-2014-0252

Niedergassel, B., \& Leker, J. (2011). Technovation Different dimensions of knowledge in cooperative R \& D projects of university scientists. Technovation, 31(4), 142-150. https://doi.org/10.1016/j.technovation.2010.10.005

Nooshinfard, F., \& Nemati-Anaraki, L. (2014). Success factors of inter-organizational knowledge sharing: A proposed framework. Electronic Library, 32(2), 239-261. https://doi.org/10.1108/EL-02-2012-0023

Pedersen, T. H. (2017). Analysis of the antecedents of knowledge sharing and its implication for SMEs internationalization. Retrieved from https://brage.bibsys.no/xmlui/bitstream/handle/11250/2460262/PedersenTH.pdf?sequence=1

Razmerita, L., Kirchner, K., \& Nielsen, P. (2016). What factors influence knowledge sharing in organizations? A social dilemma perspective of social media communication. Journal of Knowledge Management, 20(6), 1225-1246. https://doi.org/10.1108/JKM-03-2016-0112

Rego, A., Pinho, I., Pedrosa, J., \& Pina E. Cunha, M. (2009). Barriers and Facilitators to Knowledge Management in University Research Centers: An Exploratory Study. Management Research: Journal of the Iberoamerican Academy of Management, 7(1), 33-47. https://doi.org/10.2753/JMR1536-5433070103

Rosendaal, B., \& Bijlsma-Frankema, K. (2015). Knowledge sharing within teams: Enabling and constraining factors. Knowledge Management Research and Practice, 13(3), 235-247. https://doi.org/10.1057/kmrp.2013.45

Rutten, W., Blaas - Franken, J., \& Martin, H. (2016). The impact of (low) trust on knowledge sharing. Journal of Knowledge Management, 20(2), 199-214. https://doi.org/10.1108/JKM-10-2015-0391

Sajjid M, M. Z. I., \& Hasan, J. I. (2015). Organizational culture, structure, technology infrastructure and knowledge sharing. Vine, 45(1), 6788. https://doi.org/10.1108/VINE-05-2014-0037

Sandeep, V., \& Rayees, F. (2014). Knowledge Sharing Orientation and Its Relationship with Business Performance : A Structural Equation Modeling Approach. IUP Journal of Knowledge Management, 12(3), 17-41. https://doi.org/10.4018/ijkm.2014070103 


\section{ENTREPRENEURSHIP AND SUSTAINABILITY ISSUES}

ISSN 2345-0282 (online) http://jssidoi.org/jesi/ 2020 Volume 8 Number 1 (September) http://doi.org/10.9770/jesi.2020.8.1(3)

Siakas, K. V., Georgiadou, E., \& Balstrup, B. (2010). Cultural impacts on knowledge sharing: Empirical data from EU project collaboration. Vine, 40(3), 376-389. https://doi.org/10.1108/03055721011071476

Søndergaard, S., Kerr, M., \& Clegg, C. (2007). Sharing knowledge: Contextualising socio-technical thinking and practice. Learning Organization, 14(5), 423-435. https://doi.org/10.1108/09696470710762646

Swift, P. E., \& Hwang, A. (2013). The impact of affective and cognitive trust on knowledge sharing and organizational learning. Learning Organization, 20(1), 20-37. https://doi.org/10.1108/09696471311288500

Vij, S., \& Farooq, R. (2014). Multi-Group Moderation Analysis for Relationship between Knowledge Sharing Orientation and Business Performance. International Journal of Knowledge Management, 10(3), 36-53. https://doi.org/10.4018/ijkm.2014070103

Wang, S., \& Noe, R. A. (2010). Knowledge sharing: A review and directions for future research. Human Resource Management Review, 20(2), 115-131. https://doi.org/10.1016/j.hrmr.2009.10.001

Wickramasinghe, V., \& Widyaratne, R. (2012). Effects of interpersonal trust, team leader support, rewards, and knowledge sharing mechanisms on knowledge sharing in project teams. Vine, 42(2), 214-236. https://doi.org/10.1108/03055721211227255

Witherspoon, C. L., Bergner, J., Cockrell, C., \& Stone, D. N. (2013). Antecedents of organizational knowledge sharing: A meta-analysis and critique. Journal of Knowledge Management, 17(2), 250-277. https://doi.org/10.1108/13673271311315204

Yao, L. J., Kam, T. H. Y., \& Chan, S. H. (2007). Knowledge sharing in Asian public administration sector: The case of Hong Kong. Journal of Enterprise Information Management, 20(1), 51-69. https://doi.org/10.1108/17410390710717138

Abdul ROHMAN is currently a Doctoral student in Department of Management in Universitas Negeri Jakarta. His research interests cover organizational behaviour and human resource management.

ORCID ID: orcid.org/0000-0001-9202-7558

Anis ELIYANA is a Professor in Department of Management in Universitas Airlangga. She works as a lecturer in Department of Management in Universitas Airlangga as well as Universitas Negeri Jakarta. Her research interests cover organizational behavior and human resource management.

ORCID ID: orcid.org/0000-0003-2172-5935

Dedi PURWANA is a Professor in Department of Management in Universitas Negeri Jakarta. He works as a lecturer in this department. His research interests cover organizational behavior, entrepreneurship and human resource management.

ORCID ID: orcid.org/0000-0001-6475-351X

HAMIDAH is a Professor in Department of Management in Universitas Negeri Jakarta. She is currently the study program coordinator as well as a lecturer in this department. Her research interests cover organizational behavior and human resource management.

ORCID ID: orcid.org/0000-0003-4976-8742

Copyright (C) 2020 by author(s) and VsI Entrepreneurship and Sustainability CenterThis work is licensed under the Creative Commons Attribution International License (CC BY). http://creativecommons.org/licenses/by/4.0/

(c) $\underset{\mathrm{EY}}{\mathrm{E}}$ Open Access 